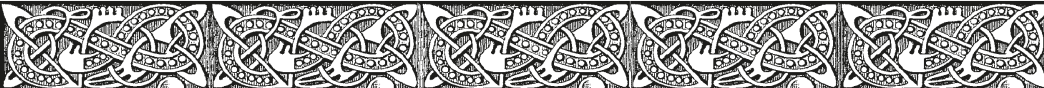

UDC 811.113.5

Elvira Myachinskaya

St. Petersburg State University

\title{
THE FACTOR OF SCANDINAVIAN INFLUENCE IN THE HISTORY OF ENGLISH
}

For citation: Myachinskaya E. The factor of Scandinavian influence in the history of English. Scandinavian Philology, 2019, vol. 17, issue 1, pp. 22-35. https://doi.org/10.21638/11701/spbu21.2019.102

Scandinavian influence in the history of English caused by the Old Norse and Old Danish invasions of the $8^{\text {th }}-$ early $11^{\text {th }}$ centuries is a popular topic in historical studies. The specific nature of the English-Scandinavian contacts explains the fact that the results were registered in the Middle English period. Traditionally attributed to Scandinavian influence are numerous loan words, certain elements of consonantal system, reduction and loss of unstressed inflexions and the change of the morphological type. The paper aims at reconsidering the Scandinavian impact and argues that the evolution of systemic linguistic levels (phonology and morphology) followed inherent English or Germanic regularities, with Scandinavian only fleshing out the existing skeleton. Lexical borrowings, though numerous, were for the Old English period cognitively redundant, parallel to the existing Anglo-Saxon vocabulary. Phonologically, [g], [k] before front vowels and [sk] instead of [J], are considered indication of Scandinavian loans but do not introduce anything new in the phonological system as inherent English phonemes are to be found in similar positions, cf. keen, geese, ask. Scandinavian words fill existing patterns, thus merely increasing the functional load. Morphologically, the reduction and loss of unstressed endings were due to the general Germanic typological transition of the root morpheme from free quantity to syllabic cut and syllabo-morphemic root structure. Language contacts may have only accelerated the process.

Keywords: Scandinavian influence, language contact, loan words, phonological patterns, morphological typology.

Language contacts, a necessary component in the history of human society starting at a certain stage of its development, as a rule leave traces - of different scope and effect - upon all communication partici- 
pants. The interaction of English and Old Scandinavian languages (Old Norse and Danish) is specific for its prolonged period (Old English and part of Middle English), for its regularity and stadiality. Three aspects should be distinguished in a topic called "Scandinavian influence in the history of the English language": contact interaction carried out by specific people in a specific historical period; language assimilation of borrowed material - systemic and structural - and research interpretation of the results of the Anglo-Scandinavian relations. To illustrate the latter aspect a quote from a recent British publication may be appropriate. "The effects on English of contact with Old Norse may therefore be reckoned as unusually profound. If this influence had not happened $\langle\ldots\rangle$ the English language would now have been quite different" [Dance, Schorn, 2018, p. 57].

Our point of view, based on the inclusion of the material under study in a wider linguistic theoretical context, is directly opposite to the quoted. Our main thesis is that without the Scandinavian element, the systemic levels of the English language would have a modern look anyway. We see our task in showing the real nature of the contact and in many cases re-qualifying the "influence", showing either a different level of interaction or a different character of the Scandinavian presence.

\section{SCANDINAVIAN INVASION AND CERTAIN STAGES OF ITS STUDY}

Cultural ties between the Anglo-Saxons and the Scandinavians already existed in the early $7^{\text {th }}$ century, as evidenced by the findings in the famous excavation of the ancient Viking ship-burial with a wealth of Anglo-Saxon artefacts of outstanding art-historical and archaeological significance, including Scandinavian decoration and arms, at the small place Sutton-Hoo [Melnikova, 1987, p.5-7]. The later links that had brought about the intensive linguistic impact are far from being cultural, though.

Scandinavian influence upon the evolution of English is a theme mandatory for any history of English. Karl Brunner provides a detailed chronological summary of sea raids and consecutive settlement of Northern Germanic peoples on the British territory, giving extensive onomastic evidence [Brunner, 1955, p.109-120]. Also in the mid-fifties, Natalia Amosova investigated linguistic and sociocultural features 
of the periods of Scandinavian conquest, resettlement and assimilation [Amosova, 1956, p. 114-121]. Thus, the topic has attracted a long-standing attention and close observation and is vital up to date.

The seminal Cambridge "History of the English Language" in the index to the second volume contains the following subjects under the sub-title of Scandinavian influence: "Scandinavian influence on later Middle English alliterative poetry; influence on lexis; influence on northern dialect forms; influence on personal names; influence on place names; influence on pronouns; influence on she; spread of at; use of get" [Cambridge..., 2001, p. 697]. Not mentioned in the list, yet present in the textual discussion, are questions of phoneme composition of the loan words, of the morphological evolution and even the syntax. This list alone shows the great scope and diversity of Scandinavian elements in English and the acute interest of scholars to both serious problems and minute details. We find it upsetting that all of these are termed "influence". A most recent book on the history of English intended for Russian BA students of English also insists on the influence that Scandinavian invasion caused in the evolution of English [Brodovich, 2018, p. 37].

Evidence of undying interest to Nordic loan words is the present day British Gersum Project: "The Scandinavian Influence on English Vocabulary" - a three- year research project funded by the Arts and Humanities Research Council - AHRC. The name of the project goes back to a Middle English word of Scandinavian origin "gersum" meaning "treasure, hoard". Researchers from the Universities of Cambridge and Cardiff aim at an on-line catalogue of more than 1000 words presumably Scandinavian in origin selected from the corpus of Northern English poetic works of the Middle English period. Dr. Richard Dance, the leader of the project writes," They [words of Old Norse origins] include such basic modern-day items as sky, egg, law, leg, call, take, window, knife, die and skin $\langle\ldots\rangle$ as well as medieval words as diverse and intriguing as hernez 'brains', muged 'drizzled' stange 'pole', and wothe 'danger. These are cultural artefacts that link us directly to the Viking era [Dance, 2017, p. 15]. Symptomatic in this quotation is the term "cultural artefacts" applied to lexical units. By this, language elements acquire a new status equaling them with material cultural and historical objects, thus moving them to a sphere of cultural values. The author uses the words "diverse and intriguing" to describe the weird archaic lexemes, such words are more appropriate for literary criticism than linguistics, Another quotation from 
R. Dance supports and specifies this assumption, "The Vikings had a major and lasting impact, and their legacy still resonates strongly in modern constructions of British identity and heritage" [Dance, 2017, p. 15].

We thus understand that Scandinavian borrowings attract modern scholars for their cultural linguistic value, as an inherent part of the British national identity, which indicates that their relevance and the relevance of their study lie in a different plane - that of cultural and social value.

\section{THE NATURE OF LANGUAGE CONTACTS AND LEXICAL BORROWINGS}

In all kinds of research on Nordic influence, lexical borrowings take the pride of the place. Barbara Fennell gives an estimate of the number of borrowed words at the level of 900 and geographical names (we do not consider them here) about 1,400 [Fennell, 2001, p.90].

According to David Burnley [Burnley, 2001, p.419] the contacts between the speakers of the two languages were in the domain of everyday life, mainly in farming. Anglo-Saxon and Scandinavian settlements were similar, their inhabitants had comparable way of life and occupations; their relationship lacked superiority of one side over the other, as is often typical of invasions. As a result, the loan word vocabulary is not marked socially or stylistically. Well-known is the chronological paradox: contacts with the Norwegians and Danes took place in the Anglo-Saxon period, while the main amount of borrowings was recorded in Middle English. A plausible explanation to this is the oral nature of communication between illiterate peasants and the absence of written tradition in that stratum at the time. D. Burnley also thinks that there existed the West Saxon standard of writing, which precluded the penetration of Nordic words in the West Saxon dialect because these words were of non-standard and non-literary status [Burnley, 2001].

Christopher Mulvey sees three reasons for the above-mentioned paradox: 1) at the initial stage of the invasion the British feared and hated the Norse and strongly opposed to the assimilation of their tongue; 2) writing is more conservative than oral speech; 3) after the split into Danelag and Anglo-Saxon England, the West Saxon dialect became the leading dialect, with the majority of literary work and documents written in it. All these prevented the inroad of Danish words into English 
[Mulvey, 2018, p. 41-42]. The latter factor, mentioned by both scholars is sociolinguistic and cultural, and, no doubt, the most powerful.

Whereas French and Latin loans are marked according to many sociolinguistic, cultural and stylistic parameters, the everyday loans from the Norse are not only unmarked and neutral, they are also redundant as they duplicate lexis already present in the English vocabulary (with a minor exception of nautical terms). To prove this, we have taken several words from the list of loan words in Burnley's research [Burnley, 2001, p. 421] (we use them in their modern English form) and supplied them with a corresponding Anglo-Saxon word.

See, for example, anger || torn, grama; to die \| sweltan, steorfan; happy || sæliz, wynsum myriz; sky || heovon, volken; to take\| niman; law \| riht, (perhaps with a wider meaning); to want || willan;, bag || foetels; ill || yfel; to smile || smearcian; fog || mist; window || eaghyrf, mud || scearn, knife \| seax (K. Brunner supposed that a Scandinavian knife had a different shape [Brunner, 1955, p. 123]).

In other words, from the cognitive point of view, the body of Nordic loan words had not affected either the system of semantic oppositions or the picture of the world (worldview) or filled lexical gaps. This may be termed as cognitive tautology. Semantic influence is only observed in a special group of pseudo-borrowings, when there are homogeneous, or single-root, Germanic equivalents, differing in phonological composition; their collision brings about differentiation of meaning (see [Amosova, 1956, p. 118, 119]). The universally known pair of etymological doublets, shirt/skirt, is practically the only case of notional split, or delimitation, into two different "garment pieces". A similar pair with a difference in pronunciation is schedule [Jedju:1/skedju:1]; in this case, the dissociation is regional rather than lexical: British and American versions.

In the framework of Standard English, words of Danish ancestry only possess markedness of regional features - they are Northern words, which is evident only when there is a parallel non-Scandinavian word of similar meaning acting as a counterpart to the loan word. Cf. gate, from ON gata means a street in Yorkshire, while in the rest of England - a frame that closes an opening in a wall.

It is self-evident that the strongest Scandinavian input and imprint are manifested in the local dialects of the Northeast of England and in Scotland - the territories of the former Danelag. In some places Old 
Norse was a living language at the time of the Norman conquest; it was heard and spoken in the $12^{\text {th }}$ century in the Isle of Man and even later in the Shetlands and the Hebrides [Burnley, 2001, p. 418]. A possible reason for that may be the fact that in these territories an original local language was and still is Celtic and not a related Germanic language, which impeded an easy penetration. In the present day Humberside vernacular one may hear a phrase like "The bairns are laikin out ont'street» ("The children are playing in the street»), very much akin to the Modern Swedish "Barnen leker ute pa gaten" [Fennell, 2001, p. 92].

Thomason and Kaufman, who developed a detailed and sophisticated scale for assessing the level of borrowing [Thomason, Kaufman, 1988, p. 302-303], wrote about the nature of the Scandinavian influence: that Old Norse had only added "a few subtleties" of meaning and a big number of new ways of rendering old, existing meaning, often substituting an English word with a similar word of a slightly different pronunciation. We readily share this sensible point of view and would not return to the discussion of the lexical importance of Nordic words, had it not been for recent arguments stressing paramount role of Scandinavian influence for the English lexis.

\section{PHONOLOGY}

Lexical borrowing is bound to involve other linguistic levels, an aspect much more relevant for the language study than the lexicon. A traditional element discussed in historical books in the section of phonology is Scandinavian [sk] (in all positions) or [g] before front vowels (ex. give, get). Instead, we will begin with treating phonemes that usually escape researchers' attention, i.e. labiodental $[\mathrm{v}]$ and bilabial $[\mathrm{w}]$.

\section{1. $\mathrm{v} / \mathrm{w}$}

In accordance with the distribution rules of $\mathrm{OE}$ voiced and voiceless allophones of front fricatives, genuine OE words could not have a voiced labiodental $[\mathrm{v}]$ in the word-initial position; voiced allophones could occupy an intervocalic position or a position between a sonorant and a vowel [Ivanova, Chakhoyan, Belyaeva, 2006, p.60-61]. At the same time, OE had /w/, which was a bilabial consonant in the word initial position and a vocalic glide in the post-vocalic position. Both [v] and 
[w] existed in ON but their distribution differed from OE: a bilabial could only occupy a position between a consonant and a vowel and was forbidden word initially [Steblin-Kamenskij, 1955, p. 20].

In the process of borrowing from $\mathrm{ON}$, a regular substitution of $\mathrm{ON}$ initial /v/ to $\mathrm{OE} / \mathrm{w} /$ took place, because initial [v] was precluded by $\mathrm{OE}$ phonology [Myachinskaya, 2008]. Cf. ON vrangr > OE wrang "wrong", ON vapnatak > OE waepenzetac "guarded territory", ON vak $>$ ModE wake "track left by a ship in the water", ON vindauga $>\mathrm{ME}$ windowe, windohe, windoge "window", ON vanr, vant (adj.) > ME want "lacking", ON vengr $>$ ModE wing. Skeat's Etymological dictionary gives 20 loan words with the initial w- among $300 \mathrm{w}$-words of ModE [Skeat, 1911].

Belonging to the w-group are wh- ModE words $<\mathrm{OE} \mathrm{hw}=\mathrm{ON}$ hv, ex. ModE whin $<$ ME whynne = Sw hven "bentgrass"; ModE whirl $<$ ME wherflen = Icel. hvirfla "to turn" (only four words in [Skeat 1911]). If $\mathrm{ON} / \mathrm{v} /$ was not initial, it was not changed to $\mathrm{OE} / \mathrm{w} /$, because voiced fricatives were regular in this position in OE. Cf. ME thriven \| ON prifa "to seize, rasp"

Later, in the ME period, the dephonologization of the feature of length (quantity) brought about the phonologization of the feature of voice, making it distinctive. As a result, voiced and voiceless allophones of front fricatives became independent phonemes and spread to positions uncharacteristic earlier. In particular, voiced /v/ became possible word initially. In these circumstances, Scandinavian words with initial $/ \mathrm{v} /$ did not change it to $/ \mathrm{w} /$ in the process of assimilation (domestication). Examples - Viking, Valkyria, Valhalla - are not numerous, only a few words in a flood of contemporary French and Latin loan-words.

Thus, the study of this group of words gives a researcher a tool, a method of "reverse reconstruction", which allows finding systemic regularities. If the process of borrowing involves a predictable substitution of one phoneme by another, it indicates a prohibiting rule in the receiving system of phonemes. The change in the regulation of borrowing signals the change in the system of the receiving language.

A similar situation existed in the case of French and Latin loan words borrowed in the ME and EModE, only more noticeable and discussed by scholars. Early borrowings changed initial voiced fricative to voiceless, cf. Lat. vannus > OE fann, "a fan", Lat. versus > OE fers "verse", Lat. Virgil > OE Fergilius [Lass, 2001, p. 58]. In the ME and later a very numerous group of v-initial words found its way into English, such as victory, very, voice, 
etc. R. Lass looks for an explanation to this in non-systemic factors, "Old English was not "receptive" to initial [v]; something must have happened later to prompt the unmodified borrowing of voiced fricatives <...> It is uncertain what this was...» [Lass, 2001, p.58]. He considers one of the probable reasons for the appearance of initial /v/ in the big amount of words appearing in the contact situation so that English speakers got used to the sound of [v] and [3]. In a way, this is a psychological explanation, which we find perfunctory. True, such an eminent scholar as R.Lass offers other factors as well, such as dialectal difference in voice distribution, stages of voice becoming an independent feature, of the fall of geminates, etc. [Lass, 2001, p. 58-60]. Yet the question of the cause of the evolution remains open. The answer to the question may be found in the theory of typological prosodic evolution of the root morpheme in Germanic languages proposed by Yury Kuzmenko [Kuzmenko, 1991, p.256-260] and elaborated for English by Yury Kleiner [Kleiner, 2010]. The move from one typological prosodic stage, namely from OE opposition of free quantity, or mora-counting, to the next stage, to a correlation of isochrony, or syllable levelling, must be the reason. Isochronous distinctive feature is that a root morpheme is always long and syllabic quantity is distributed between the elements of the syllable (consonants and vowels), thus causing the disappearance of geminate consonants as independent phonemes and in this way triggering the mechanism of length dephonologization and voice phonologization described above.

\section{2. $3 / \mathrm{g}, \mathrm{k} / \mathrm{ch}$}

In the prehistoric, pre-literate period there was an Anglo-Frisian splitting of guttural $\mathrm{k}$ and $\mathrm{g}$ into velar or palatal sounds depending upon the quality of the following vowel. In OE, the word initial position followed by front vowels was occupied by the palatal stop g' and palatal spirant 3', cf. OE (West Saxon) ziefan, OFr zieva "to give" [Brunner, 1955, p. 74-75]. In Northern Germanic languages, i.e. Scandinavian this split did not happen and there was no palatalization before front vowels. Hence, OE words ziefan and zietan were to become Present day *yive and ${ }^{*}$ yet, but a quasi-borrowing of the Norse form of the same words with initial g- resulted in the Present day forms.

In $\mathrm{OE}[\mathrm{g}]$ stands before back vowels and it is also possible before the front vowels that were the result of i-mutation, ex. OE gōs (sing.) - 
*gōsi > gēs (plur.), "goose-geese". In such a way, the position before front vowels became permissible in $\mathrm{OE}$, which opened the way for ON borrowings to join an existing pattern.

OE palatal back stops turned into affricates $[\mathrm{t} f]$ and [dz], a process termed "assibilation". It is a fact that the change got a written reflection only in ME, with the arrival of Norman scribes. For that reason, the relationship between OE palatal/non-palatal may be clarified only by circumstantial evidence, in particular by the present day dialectal distribution of assibilated/non-assibilated forms and the analysis of phonomorphological alternation in declension paradigms.

Phono-morphological alteration is typical for OE paradigms due to various phonological changes, such as ablaut, vowel mutations, positionally conditioned alteration of voice feature and palatalization feature. In our case, the alteration of a palatal/non-palatal, or, later, assibilated/ non-assibilated root final consonant depends of the vowel quality of the attached case inflection. In the paradigms of $-a-,-j a$ - and $-i$ - noun declensions OE had morpho-phonemes /k-k', /g-g'/, or /k-t $/$, /g-dz/ enabling this type of alteration in the OE phonological system, without external interference. A regular fixed variation of the Russian type otets - otche (" $f a$ ther" (Nom.) - "father" (Voc.) did not arise because at the time English was the field for intensive morphological reduction and formal levelling.

Still, there were alternating doublet word-forms of the type dike/ dick - ditch that are usually ascribed to the co-existence of $\mathrm{OE}$ and ON. We find fruitful in this situation to use the method of geographical distribution analysis, both ME and ModE. Gill Kristensen's "Survey of Middle English Dialects" shows that non-assibilated forms may also appear in Southern regions, far outside the territory of Danelag, cf. in Gloucestershire (West Saxon territory) OE beorc "birch" is registered (in 1327) in the name Berkeley (with [k]) [Kristensenn, 1987, p. 113].

\section{3. sk/sh}

A special place belongs to ON $s k$ consonant cluster. In OE $s k$ was a consonantal group capable of metathesis. In it, $k$ was palatal before front vowels, but eventually spread to the position before back vowels word medially and for a long time remained velar word- finally. Despite all this, $s k>/ \int /$ in all positions and was revived in English phonotactics by numerous Norse borrowings. The Nordic influence lies exclusively 
in the sphere of phonotactics because independent phonemes /s/ and $/ \mathrm{k} /$ were part of OE phoneme inventory. Next to Nordic loan words, there are similar Latin borrowings, ex. Scripture, school, skeleton, scrutiny, etc. There are also native English words with word final $s k$, cf. ask $<\mathrm{OE}$ askian, axian from ${ }^{*}$ askojan or tusk $<\mathrm{OE}$ tusk, tux [Brunner, 1955, p. 279]. Both words comprise OE forms with metathesis, which allows an assumption that it was the metathesis that prevented $/ \mathrm{J} /$ formation. Later, after the appearance of $/ \delta /$, the metathesis reverted to $s k$, at which time ask and tusk were lost in a horde of Norse loanwords.

Also specific is the formation of words with the initial scr-cluster. In some cases it changed to shr-, cf. shrink< OE scrincan; in others it did not, cf. scream < ${ }^{*}$ scrēman, in analogy, perhaps, with ON words. Surprising is a pair of doublets shriek / screech, with the same meaning: in the first word, the initial consonant is of the English type and the final consonant is Norse-type. In the second word - vice versa, a reverse pattern. In such a way. peculiar phonological oxymorons arose.

To sum up, Scandinavian words with their specific features add weight, or give flesh, to phonological or phonotactic patterns existing in $\mathrm{OE}$ and ME. This sort of participation can be classified as the increase of the functional load of this or that phonological unit.

\section{INFLECTIONAL REDUCTION AND THE CHANGE OF THE MORPHOLOGICAL TYPE}

There is another myth concerning the significance of Scandinavian influence: since $\mathrm{OE}$ and $\mathrm{ON}$ belonged to the same Germanic group of languages but differed as West Germanic and North Germanic, their semblance showed itself in the root morpheme while dissimilarity touched inflexion, which was the reason for eliminating dissimilitude through reduction of inflections and disappearance of nominal categories. First expressed by O. Jespersen, this idea is still active. One has to admit that the idea is not devoid of reason and it may be valid for some piece of historical linguistic reality, but it is true only for a very small segment of the typological reconstruction (for criticism see [Ivanova, Chakhoyan, Belyaeva, 2006, p. 127-128]).

To start with, viewed against Proto-Germanic, OE had already a seriously destroyed morphology. Homonymy of nominal and verbal 
endings was widespread and spreading further, causing inflexion desemantization and loss of the functional load. Cf., the $-\bar{o}$ - feminine nominal declension had an $-e$ ending in all oblique cases of the singular and an $-a$ ending in the Nominative, Genitive and Accusative cases in the plural. In ME Midland dialects, the verb had an ending -en in the form of Infinitive, in the plural of Indicative and Subjunctive, as well as in the Past participle. What is traditionally called reduction - the ME substitution of a fully articulated vowel by the neutral $[ə]$, spelt $-e-$ indicates a new linguistic era. Grammatical categories which used to be expressed by inflection within one word (synthetically, together with the lexical meaning) are no longer expressed in this way. Instead, linguistic means outside the notional word- prepositions, articles, particles, word-order - come to the forefront and express categories analytically. (Fully disappearing was only the category of gender).

Thus, the reduction followed by the loss of unstressed endings is an intrinsic tendency of English.

Secondly, the explanation of this process is rooted more deeply in the Germanic language typology. Characteristic for Germanic languages from the earlier stages was consolidation, prominence of the root manifested in various ways. In particular, because of Germanic vowel mutations and ablaut alterations the root took upon itself expression of grammatical categories together with the lexical meaning. This resulted in both the reduction of unstressed morphology and the apocope of endings, which are thus grammatically conditioned. [Kuzmenko, 1991, p. 242-243], but language contacts can accelerate the process or act as its catalyst. Thus, we can, argue that analogous evolution of morphological systems of English and a part of Scandinavian languages reflects their parallel development in accordance with general tendencies, rather than the influence of one language upon the other.

\section{CONCLUSIONS}

1. Lexical borrowings are redundant and duplicate already existing English lexemes. A big amount of surviving Norse loans is due to their being mainly part of Northern dialectal vocabulary; this lexicon is functionally limited. 
2. The newly arising (or still remaining) interest of British scholarly circles to the issue of Norse lexis is motivated by sociocultural factors of the national identity.

3. The phonological aspect of borrowing is relevant and methodologically significant to characterize $\mathrm{OE}$ and ME phonological systems, i.e. as a research tool. The phonological features that are introduced through borrowings follow the patterns that existed in $\mathrm{OE}$ and $\mathrm{ME}$, though sometimes peripheral. The main influence is the increase of the functional load.

4. The reduction of unstressed endings in $\mathrm{OE}$ and $\mathrm{ME}$ is a general tendency of Germanic languages. English and Scandinavian went parallel courses mutually reinforcing the evolutionary trend

5. Undoubtedly, the Scandinavian presence in the history of England was very significant, but the impact on the evolution of the language, in our opinion, is overestimated. The present study has sought to show that the direction of English evolution was predetermined by intralinguistic and typological factors, and the Scandinavian presence participated in this evolution only by giving flesh to the immanent processes, rather than inducing them.

\section{LIST OF ABBREVIATIONS}

OE - Old English, Anglo-Saxon

ME - Middle English

EModE - Early Modern English

ModE - Modern English

ON - Old Norse, Old Icelandic

OFr. - Old Frisian

Sw. - Swedish

Icel. - Icelandic

Lat - Latin

\section{REFERENCES}

Amosova N.N. Etimologicheskiye osnovy slovarnogo sostava angliiskogo yazyka [Etymological Roots of Present-Day English Vocabulary]. Moscow: Izdatel'stvo literatury na inostrannykh yazykakh, 1956. 218 p. (In Russian)

Brodovich O. I. Istoriya angliiskogo yazyka [History of English]. St. Petersburg: Izdatel'stvo RHGA, 2018. 184 p. (In Russian)

Brunner K. Istoriya angliiskogo yazyka [History of English]. Vol.1. Moscow: Izdatel'stvo inostrannoy literatury, 1955. 392 p. (In Russian)

Burnley D. Lexis and Semantics. The Cambridge History of the English Language. Vol. 2. Ed. by N. Blake. Cambridge University Press, 2001. 332 p. 
Cambridge History of the English Language. Vol.II. Cambridge University Press, 2001.

Dance R. The Gersum project. The Scandinavian influence on English vocabulary. Transactions of the Yorkshire Dialect Society. Pt. CXVII. Vol.XXIII. 2017. P. 14-15.

Dance R., Schorn B. Tykes and Vikings: Looking for the Old Norse influence on Northern English Vocabulary. Transactions of the Yorkshire Dialect Society. Pt. 118. Vol. 23. 2018. P. 46-78.

Fennell B. A History of English. A Sociolinguistic Approach. Oxford: Blackwell Publishers, 2001. $284 \mathrm{p}$.

Ivanova I. P., Chakhoyan L.P., Belyaeva T. M. Istoriya angliiskogo yazyka [History of English]. $3^{\text {rd }}$ ed. St. Petersburg: Avalon, Azbuka-klassika, 2006. 560 p. (In Russian)

Kleiner Ju. Problemy prosodiki [Problems of Prosodics]. $2^{\text {nd }}$ ed. St. Petersburg: SPbGU, 2010. 112 p. (In Russian)

Kristensenn G. Survey of Middle English Dialects 1290-1350. The West Midland Counties. Lund: Lund University Press, 1987.251 p.

Kuzmenko Ju. Fonologicheskaya evolutsiya germanskikh yazykov [Phonological evolution of Germanic languagies]. Leningrad: Nauka, 1991. 285 p. (In Russian)

Lass R. Phonology and Morphology. The Cambridge History of the English Language. Vol. II. Cambridge University Press, 2001.

Melnikova Ye. A. Mech I lira [A Sword and a Harp]. Moscow: Mysl, 1987. 203 p. (In Russian)

Mulvey Ch. The English Language and the Danish Language. Transactions of the Yorkshire Dialect Society. Pt. 118. Vol.23. 2018. P. 35-45.

Myachinskaya E. I. Kharakter skandinavskogo vliyaniya v istoricheskoy fonologii anglijskogo yazyka [The character of Scandinavian influence in English historical phonology]. Anglistika XXI veka [Anglistics of the XXI century]. Proceedings of the IV All-Russia Conference. St. Petersburg: SPbGU, 2008. P. 132134. (In Russian)

Skeat W. A Concise Etymological Dictionary of the English Language. Oxford, 1911. Steblin-Kamenskij M.I. Drevneislandskij Yazyk [Old Icelandic]. Moscow: Izdatel'stvo literatury na inostrannykh yazykakh, 1955. 286 p. (In Russian)

Thomason S., Kaufman T. Language Contact, Creolization and Genetic Linguistics. Berkeley, CA: University of California Press, 1988.

\section{Эльвира Ивановна Мячинская}

Санкт-Петербургский государственный университет

\section{ФАКТОР СКАНДИНАВСКОГО ВЛИЯНИЯ В ИСТОРИИ АНГЛИЙСКОГО ЯЗЫКА}

Для цитирования: Myachinskaya E.I. The factor of Scandinavian influence in the history of English // Скандинавская филология. 2019. Т. 17. Вып. 1. С. $22-$ 35. https://doi.org/10.21638/11701/spbu21.2019.102 
Скандинавское завоевание Британии в древнеанглийский период оставило на разных уровнях английского языка неизгладимые и множественные следы, лингвистическое значение которых, на наш взгляд, переоценивается лингвистами и людьми, пишущими об истории английского языка. Цель настоящей публикации - поставить скандинавский материал в рамки английских и германских закономерностей и тем самым определить место этих заимствований. Так, многочисленные (около 1000) лексические заимствования в основном когнитивно избыточны, поскольку встают в корреляцию с уже существующими древнеанглийскими словами и редко вводят новые понятия. В составе заимствованных слов привнесены фонологические черты, которые принято считать скандинавскими (напр. [g.], [sk] перед переднеязычными гласными). Однако эти черты следуют существовавшим в древне- и среднеанглийском фонологическим и фонотактическим моделям, лишь наполняя их языковым материалом, т.е. увеличивая их функциональную нагрузку. Важность заимствований в том, что они служат лингвистам индикатором того, каковы были фонологическая система принимающего языка и ее эволюция, т.е. анализ заимствований используется как исследовательский метод. Редукцию безударных окончаний, часто приписываемую сосуществованию с однокоренными скандинавскими словами, следует рассматривать как проявление германской типологической тенденции грамматического усиления корня, сопровождаемого грамматической редукцией флексии. В целом термин «скандинавское влияние» следует понимать как «участие» или «присутствие» в эволюции английского языка.

Ключевые слова: скандинавское влияние, история английского языка, заимствования, увеличение функциональной нагрузки, редукция окончаний, фономорфологическая типология.

\section{Elvira Myachinskaya}

PhD in Philology, Senior Lecturer,

St. Petersburg State University,

7-9, Universitetskaya nab., St. Petersburg, 199034, Russia

e-mail: e.myachinskaya@spbu.ru

\section{Эльвира Ивановна Мячинская}

доцент, кандидат филологических наук,

Санкт-Петербургский государственный университет,

Россия, 199034, Санкт-Петербург, Университетская наб., 7-9

e-mail: e.myachinskaya@spbu.ru

Received: June 22, 2018

Accepted: April 15, 2019 